原著

\title{
ニフェカラントが有効な誘発性心室頻拍の 電気生理学的特徵
}

辰本明子*1 櫻田春水*1 小宮山浩大*1 岡崎英隆 ${ }^{* 1}$ 弓場隆生 ${ }^{* 1}$ 谷井博亘 ${ }^{* 1}$ 小泉章子*1 田辺康宏*1 深水誠二*1 山口博明*1 手島 保*1 西崎光弘*2 平岡昌和*3

ニフエカラントは難治性心室頻拍 (VT) に用いられる薬剤であるが，どのような VTにより有効であるかは明らかでない。そのためプログラム刺激 (PES) により誘 発されたVTにニフェカラントを使用し, 有効性に関与する因子を検討した.【方法】 PESで血行動態不安定な持続性VTが誘発された 14 例にニフェカラントを投与 (5 分で $0.3 \mathrm{mg} / \mathrm{kg}$ 静注後, $0.4 \sim 0.8 \mathrm{mg} / \mathrm{kg} / \mathrm{hr}$ で持続静注)し, 刺激を繰り返し

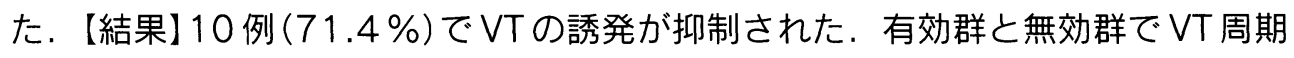
長 $(C L)$, 使用前後の右室有効不応期 (ERP), QTcを比較したところERP, QTcは 両群に差を認めなかつたが, VTCLは有効群で有意に短縮していた。【結論】ニフェ カラントはVTCLの短い頻拍により有効であることが示された.

(心電図, $2007 ； 27 ： 154$ 159)

\section{I.はじめに}

\section{ニフェカラントは現在日本で使用可能な唯一の静}

\begin{tabular}{|ll|}
\hline Keywords & ・心室頻拍 \\
& ・塩酸ニフェカラント \\
& ・周期長 \\
\hline
\end{tabular}

*1東京都立広尾病院循環器科

（干 150-0013 東京都渋谷区恵比寿 2-34-10）

$* 2$ 横浜南共済病院循環器センター

$* 3$ 東京医科歯科大学
注用 III 群抗不整脈薬である. 本薬剤のもつカリウム チャネル遮断による不応期延長効果は, 従来リエン トリー性不整脈に対し多用されてきたナトリウム チャネル遮断薬のもつ伝導抑制作用とは異なる抗不 整脈作用である。そのため, 特に難治性心室頻拍 (ventricular tachycardia：VT)に対する有効性が注 目されているが，どのようなVTにより有効である かは明らかではない1), 2).

今回われわれは, 電気生理検査によるVT誘発試 験を行い, ニフェカラント投与前後の電気生理学的

Electrophysiological characteristics of induced ventricular tachycardia effectively treated by Nifekalant hydrochloride Akiko Tatsumoto, Harumizu Sakurada, Kota Komiyama, Hidetaka Okazaki, Takao Yuba, Hironobu Tanii, Akiko Koizumi, Yasuhiro Tanabe, Seiji Fukamizu, Hiroaki Yamaguchi, Tamotsu Tejima, Mitsuhiro Nishizaki, Masayasu Hiraoka

2006 年 9 月 1 日 原稿受領 $/ 2006$ 年 12 月 21 日 掲載承認 
特徵を検討した。

\section{II. 対象と方法}

\section{1. 対象}

当院にて 2004 年 10 月からの 12 力月間に電気生理 検査を行い，プログラム刺激（programmed electorical stimulation：PES)により，収縮期血圧が $60 \mathrm{mmHg}$ 未満に低下する持続性 VTが再現性をもっ て誘発された，基礎心疾患を有する 14 症例 (男性 10 例, 女性 4 例, 平均年齢 $62.2 \pm 10.5$ 歳)を対象とした.

電気生理検査に先立ち，本人および家族に説明を 行い，文書による同意を得た。

\section{2. 検査方法}

PESに先立ち, 全例で加算平均心電図検査および, 左室造影を行った。加算平均心電図はCorazonics 社 Predictor Unit Version6.1を使用した.

PESは以下のプロトコールで行った.

無投薬下に，まず右室心尖部 (right ventricular apex : RVA), 続いて右室流出路 (right ventricular outflow tract : RVOT) から 1 3発の期外刺激, 頻 回刺激を行った.刺激出力は拡張期閾值の 2 倍とした.

期外刺激法は $600 \mathrm{msec}, 400 \mathrm{msec} の 2$ 種類の基本 刺激周期を用いた。期外刺激の最短刺激周期は， 2 連期外刺激では $180 \mathrm{msec} ま て ゙ ， 3$ 連期外刺激では $200 \mathrm{msec}$ までとし，その範囲内で心室筋を捕捉可能 な最短刺激周期においては刺激を 5 回繰り返し行っ た. 頻回刺激は刺激頻度 $200 /$ 分 (周期 $300 \mathrm{msec}$ ) から 開始し，10/分ずつ頻度を増加させ，250/分 (周期 $240 \mathrm{msec}$ ) まで実施した。 なお, 各周期での刺激数 は10〜20拍とした.

持続性 VTが誘発された場合，同一の刺激を繰り 返し，少なくとも 2 回以上誘発されることをもって 再現性ありと判定した．持続性VTとは，30秒以上 持続するもの，あるいは30秒以下であっても血行動 態の悪化のため早急な治療を要するものと定義し た、VTが持続した場合は心室ペーシングまたは直 流通電により停止させた.

検查中は心電図, 観血的持続動脈圧, 経皮的酸素
飽和度のモニタリングを行った.

また誘発されたVTは，単形性 (同一QRS波形の 持続するもの), 多形性 $(\mathrm{QRS}$ 波形が連続的に変化す るVTで単一の QRS 波形が 5 拍以上持続しないも の), 複数単形性 (複数の波形の単形性 VTがみられ, 一つの波形から他へ移行するもの)に分類した.

\section{3. ニフェカラント投与方法}

ニフェカラントは, $50 \mathrm{mg}$ を生理食塩水 $50 \mathrm{~mL}$ で 用時溶解し，末梢静脈より投与した. $0.3 \mathrm{mg} / \mathrm{kg}$ を 5 分間で静脈注射後，引き続き $0.4 \mathrm{mg} / \mathrm{kg} / \mathrm{hr}$ にて持続 静注を開始した．持続静注開始 10 分後より，上述の PESを再度行った.PESによりVTが誘発された場 合, ニフェカラントを最大 $0.8 \mathrm{mg} / \mathrm{kg} / \mathrm{hr}$ まで増量の うえ，PESを繰り返した。なお $0.8 \mathrm{mg} / \mathrm{kg} / \mathrm{hr}$ は，本 薬凨の第 I相試験で安全性の確認された最大投与量 である ${ }^{3)}$.

症例によっては，ニフェカラント投与前には， RVAからの刺激で再現性あるVTが誘発されたた め, RVOTへの刺激を行っていない例もある。 しか し，この場合でも，ニフェカラント投与後にRVA からVTが誘発されなかった際は，RVOTからの刺 激も追加し有効性を検討した。

\section{4. 計測項目}

加算平均心電図における RMS40 值を計測し，20 $\mu \mathrm{V}$ 未満を心室遅延電位陽性とした。

左室駆出率 (left ventricular ejection fraction : LVEF)は，左室造影を用いSimpson法により計測 した.

ニフェカラント投与前後での右室有効不応期 (effective refractory period : ERP), QT 時間, RR 間隔を計測し，QT 時間，RR 間隔から QTc を算出 した。またニフェカラント投与前に誘発されたVT 周期長 (VT cycle length : VTCL)を計測した. VTCLは, 誘発されたVT中の最初の 10 拍の平均 RR 間隔とした。

\section{5. 効果判定}

ニフェカラント投与によりVTがまったく誘発さ れなくなった場合，あるいは誘発されるものの15拍 
以内に自然停止するようになった場合を有効とした。

\section{6. 統計解析}

測定値は平均 \pm 標準偏差 $(\mathrm{SD})$ で示した。有効群, 無効群の 2 群間での臨床的指標, 誘発されたVTの 電気生理学的指標，およびニフェカラント使用前後 での電気生理学的指標の比較を 2 標本 $\mathrm{t}$ 検定，もし

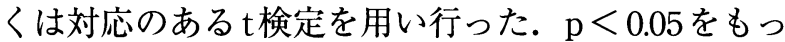
て有意差ありと判定した。

\section{III. 結 果}

\section{1. 患者の臨床的背景}

全14症例の患者背景を表1に示す. 14例の基礎心 疾患の内訳は，陳旧性心筋梗塞 11 例，心筋炎後遺症 1 例, 拡張型心筋症 1 例, 肥大型心筋症 1 例であった.
14 症例中 10 症例 $(71.4 \%)$ で，ニフェカラント投与 によりVT誘発が抑制された (有効群)。4症例 $(28.6 \%)$ では誘発抑制はみられなかった(無効群)。 有効群 10 症例のうちの 2 症例は, ニフェカラント $0.4 \mathrm{mg} / \mathrm{kg} / \mathrm{hr}$ ではVT誘発が抑制されず, $0.8 \mathrm{mg} / \mathrm{kg} / \mathrm{hr}$ まで増量し，有効性が認められた。ま た無効群のすべてで，ニフェカラントは $0.8 \mathrm{mg} / \mathrm{kg} / \mathrm{hr}$ の最大投与量まで増量した。

有効群, 無効群の 2 群間において, 年齢 (有効群 $61.3 \pm 10.7$ 歳, 無効群 $65.8 \pm 11.6$ 歳, $\mathrm{p}=0.503)$, LVEF (有効群 $52.7 \pm 19.1 \%$, 無効群 $32.8 \pm 9.6 \%$, $\mathrm{p}=0.074 ）$ に有意差を認めなかった．加算平均心電 図における RMS40 は有効群 $18.1 \pm 13.7 \mu \mathrm{V}$, 無効群 $6.5 \pm 1.7 \mu \mathrm{V}$ と無効群で低值であったが，有意差を認

表1 対象の患者背景

\begin{tabular}{|c|c|c|c|c|c|}
\hline & 年齢 (y.o.) & 性別 & 基礎心疾患 & 左室駆出率(\%) & $\begin{array}{c}\text { SAECG } \\
\text { RMS40 }(\mu \mathrm{V})\end{array}$ \\
\hline 有効群 & & & & & \\
\hline (1) & 56 & $\mathrm{M}$ & OMI & 34 & 25 \\
\hline (2) & 65 & $\mathrm{M}$ & OMI & 44 & 20 \\
\hline (3) & 42 & $\mathrm{~F}$ & 心筋炎後 & 88 & 9 \\
\hline (4) & 76 & $\mathrm{M}$ & OMI & 71 & 11 \\
\hline (5) & 56 & $\mathrm{~F}$ & OMI & 38 & 6 \\
\hline (6) & 68 & $\mathrm{~F}$ & $\mathrm{HCM}$ & 75 & 45 \\
\hline (7) & 54 & $\mathrm{M}$ & OMI & 37 & 5 \\
\hline (8) & 62 & $\mathrm{M}$ & OMI & 54 & 29 \\
\hline (9) & 57 & $\mathrm{M}$ & OMI & 34 & 16 \\
\hline (10) & 77 & $\mathrm{M}$ & OMI & 71 & 11 \\
\hline 無効群 & & & & & \\
\hline (11) & 63 & $\mathrm{M}$ & $\mathrm{DCM}$ & 31 & 9 \\
\hline (12) & 51 & $\mathrm{M}$ & OMI & 42 & 5 \\
\hline (13) & 71 & $\mathrm{M}$ & OMI & 38 & 6 \\
\hline (14) & 78 & $\mathrm{~F}$ & OMI & 20 & 4 \\
\hline
\end{tabular}

有効群のうちの 2 例 (5), (7)), および無効群のすべてでニフェカラントは $0.8 \mathrm{mg} / \mathrm{kg} / \mathrm{hr}$ の最大投与量まで増量した. 有効群, 無効群において年齢, 性別, 基礎心疾患の分布に 差を認めなかった。

OMI : 陳旧性心筋梗塞, DCM : 拡張型心筋症, HCM : 肥大型心筋症 
めなかった $(\mathrm{p}=0.126)$. ただし RMS40值 20 未満の 心室遅延電位陽性例は, 有効群 10 例中 6 例であった が，無効群では全例であった。

\section{2. ニフェカラント投与前 VT波形}

ニフェカラント投与前, 全例でRVAからの 2 連あ るいは 3 連期外刺激によりVTが誘発された。投与 前に誘発されたVTのQRS 波形は, 単形性が有効群 3 例, 無効群 3 例, 多形性が有効群 4 例, 無効群 1 例, 複数単形性が有効群 3 例, 無効群 0 例であった.

\section{3. ニフェカラント投与前後の ERP}

ニフェカラント投与後, RVAにおけるERPは全 例で延長した。有効群では投与前 $250.00 \pm$ $19.43 \mathrm{msec}$, 投与後 $309.00 \pm 17.28 \mathrm{msec}$, 無効群で は投与前 $260.00 \pm 25.82 \mathrm{msec}$, 投与後 $282.50 \pm$ $33.04 \mathrm{msec}$ であり, それぞれの群で投与前後に有意 差をもってERPが延長した（図1)が，投与前值，投 与後値は 2 群間に差はなかった.

4. ニフェカラント投与前後のQTC

ニフェカラント投与後, 全例でQTcが延長した.

\section{$\mathrm{ERP}(\mathrm{msec})$}

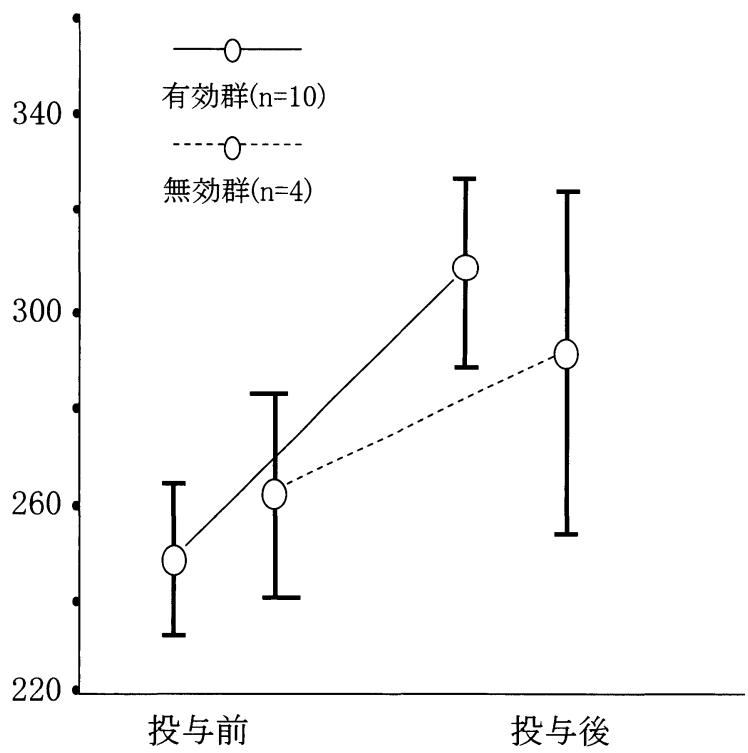

図1 ニフェカラント投与前後のRVA ERPの比較 それぞれの群で投与後にERPの有意な延長を認めたが，両 群間の差は認められなかった。
有効群では投与前 $448.70 \pm 54.55$, 投与後 $499.60 \pm$ 22.29 ，無効群では投与前 $446.00 \pm 36.40$, 投与後 $531.00 \pm 35.56$ であり，それぞれの群で投与前後に有 意差をもってQTcが延長した (図2)が, 投与前值, 投与後值には 2 群間で差はなかった。

\section{5. ニフェカラント投与前のVTCL}

投与前に誘発されたVTCLは，有効群 $195 \pm$ $23 \mathrm{msec}(165 \sim 250 \mathrm{msec}$ ), 無効群 $252.5 \pm 41 \mathrm{msec}$ (200〜 320 msec) で，有効群において有意に短かっ た $(\mathrm{p}=0.005$, 図3).

\section{IV. 考察}

\section{1. ニフェカラント有効例の臨床的特徴}

器質的心疾患に合併する不整脈治療においては, これまでしばしばナトリウムチャネル遮断薬が用い られてきた。しかし，その有効性は必ずしも高くな く，また患者の多くは，心収縮能が低下しているた め薬剤の陰性変力作用が問題であった.

本研究では，ニフェカラントの有効性が左室収縮

\section{QTc(msec)}

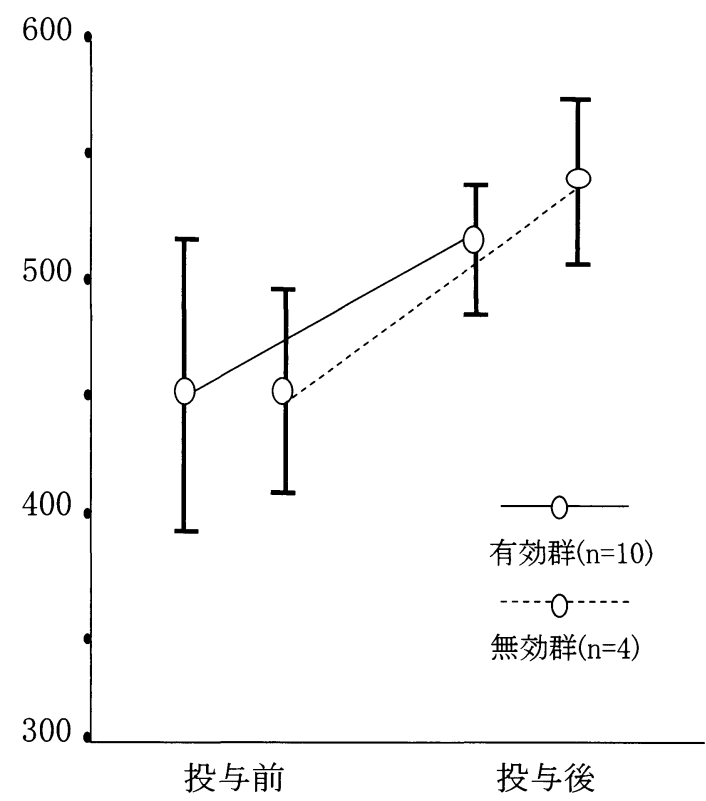

図2 ニフェカラント投与前後のQTc 時間の比較 それぞれの群で投与前後にQTc の有意な延長を認めたが, 両群間の差は認められなかった。 


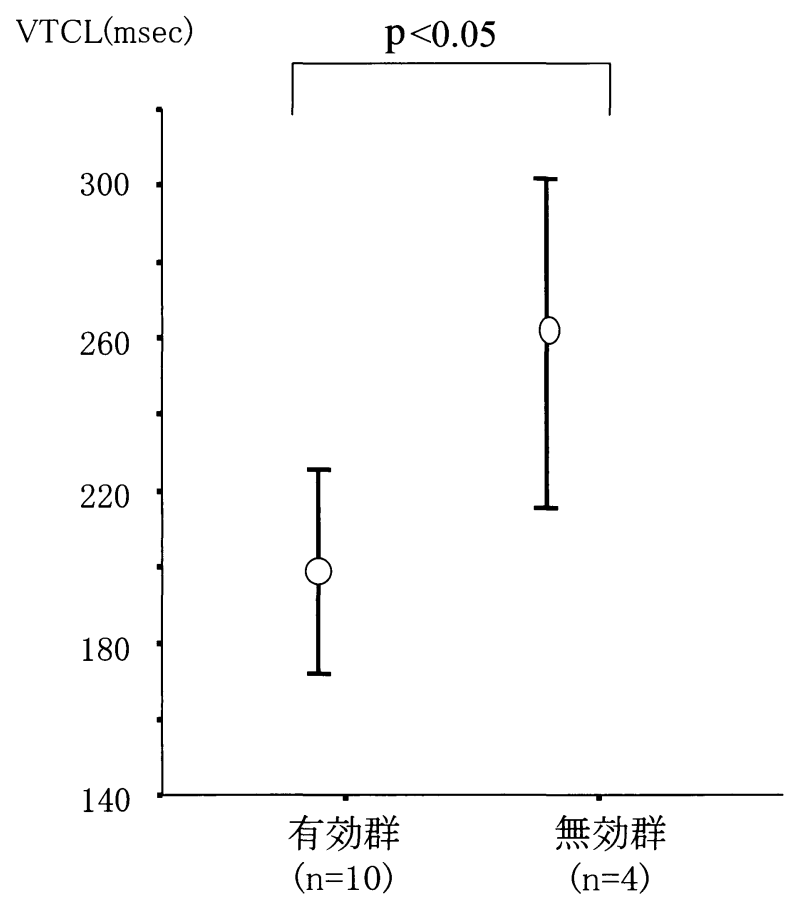

図3 ニフェカラント投与前のVT周期長の比較 周期長は無効群に比較し, 有効群で有意に短かった。

能低下症例でやや低かったが有意差はなく, LVEF 40\%以下の 7 例でも 4 例 (57.1\%) で有効であった. 本薬剤は，陰性変力作用が少ないことが知られてお り，低左心機能の患者においても，十分な量を用い ることが可能であり, 高いVT誘発抑制効果が期待 できると考えられた。

多くの症例で加算平均心電図における心室遅延電 位は陽性を示し，伝導遅延を基盤とした不整脈基質 の存在が示唆されたが，ニフェカラントの有効性に は関与しなかった。

\section{2. ニフェカラント有効例の電気生理学的特徵}

ニフェカラントは，EPSにより誘発された単形性, 多形性, 複数単形性いずれの波形のVTにも有用で あった.またこれらのVTはいずれも再現性をもっ て誘発が可能である点から，すべてリエントリー性 VTと考えられた。

右室 ERPは，いずれの群においてもニフェカラン 卜使用により延長した。 またQTcも, いずれの群に おいても使用後に10〜15\%の有意な延長を示した.
今回ニフェカラント薬剤血中濃度は測定していない が，有効不応期や，QTcの延長度からは，いずれの 群でも薬凨が十分な治療域濃度に達していたものと 考えられ，誘発抑制効果が薬剤量や濃度の影響を受 けた可能性は低いと考えられた。

ニフェカラントが有効な VTは有意に短い周期長 をもつという特徵がみられた。症例により異なるた め断定することはできないが，周期長の短い頻拍で は，長い頻拍に比べ，頻拍回路内の興奮間隙が短い 可能性が考えられる。このため，わずかな不応期延 長によっても興奮前面が不応期に衝突し, 頻拍の発 生・維持が不能となるものと考えられた。したがっ てニフェカラントはVTCLが短いVT，すなわち， より重症度の高いVTを有する症例で高い有効性が 期待できると思われた ${ }^{4)}$.

\section{3. 本研究の問題点}

ニフェカラントは静注剤のみであることから, 慢 性期管理のための内服薬への切り替えを目的とした 電気生理学的ガイド治療としての意義は必ずしも十 分ではない. また，今回われわれはニフェカラント によるVTの停止効果については検討していない. VT 持続中の使用による停止効果は，過去の報告に おいても 50 〜 $60 \%$ にどまり，これは本薬剤のも つカリウムチャネル遮断作用 $\left(\mathrm{I}_{\mathrm{Kr}}\right)$ の逆頻度依存性に よるものであると考察されている ${ }^{5}$. 本研究の意義 は，ニフェカラントによるVT誘発抑制効果を示し たことにある。すなわち, electrical stormのような 繰り返されるVT発作がみられた場合, ニフェカラン 卜投与により，再発予防効果が期待されると考えら れた。

本研究においては, $0.4 \mathrm{mg} / \mathrm{kg} / \mathrm{hr}$ で有効性が得ら れず $0.8 \mathrm{mg} / \mathrm{kg} / \mathrm{hr}$ までの増量をもって有効性の得ら れた症例が 2 症例存在した。このことから，本薬剤 に用量依存性の効果があるとも考えられる，薬剤の 使用中は高度な徐脈，QT 時間の延長や T波の形状 の変化, および血清カリウム值などに注意を要する ${ }^{6)}$ ことを前提とすれば，短期間の使用においては，投 与量の増加は試みる価值があると考えられた。 


\section{V. 結 語}

誘発性心室頻拍に対して，ニフェカラントは，基 礎疾患, 左室収縮能によらず高い誘発抑制効果を示

した。

特に, ニフェカラントが有効な VTは短い周期長 をもつという特徵がみられ，このことから，重症度 の高いVT症例において, 予防効果がより期待でき るものと考えられた.

\section{〔文献〕}

1 ) Katoh T, Mitamura H, Matsuda N, Takano T, Ogawa S, Kasanuki $\mathrm{H}$ : Emergency treatment with nifekalant, a novel class III anti-arrhythmic agent, for life-threatening refractory ventricular tachyarrhythmias : postmarketing special investigation. Circ J, $2005 ; 69$ : $1237 \sim 1243$

2 ) Yoshioka K, Amino M, Morita S, Nakagawa Y, Usui K, Sugimoto A, Matsuzaki A, Deguchi Y, Yamamoto I,
Inokuchi S, Ikari Y, Kodama I, Tanabe T : Can nifekalant hydrochloride be used as a first-line drug for cardiopulmonary arrest (CPA)? : comparative study of out-of-hospital CPA with acidosis and in-hospital CPA without acidosis. Circ J, $2006 ; 70: 21 \sim 27$

3 ）加藤貴雄, 角尾道夫, 新 博次, 黒木伸一, 金 應文, 藤 森ひろみ, 国見聡宏, 小原俊彦, 宮本新次郎, 小林利行, 平田 宏：MS-551 注射剂の第 I相試験(第 2 報)一持続静 注試験一. 臨床医薬, $1989 ； 13 ： 1675 \sim 1687$

4 ）櫻田春水, 小林洋一, 杉 薫, 片桐 敬, 馬場隆男, 円 城寺由久, 山口 徹, 岡崎英隆, 本宮武司：持続性心室 頻拍に対するMS-551注射剤の電気生理学的検査による 薬効評価. 臨床医薬, $1997 ； 13 ： 1773 \sim 1787$

5 ）大西 哲, 笠貫 宏, 庄田守男, 松田直樹, 梶本克也, 梅 村 純, 細田瑳一：難治性心室頻拍に対するMS-551注射 剂の臨床的有用性の検討. 臨床医薬, $1997 ; 13$ : $1759 \sim 1771$

6 ）遠田賢治, 布田有司, 東谷迪昭, 太田正人, 鶴崎哲士, 岡田尚之, 阪本宏志, 石川哲也, 武藤 誠, 今井嘉門, 堀江俊伸, 庄田守男, 笠貫 宏：重症虚血性心疾患に合 併した致死性不整脈における塩酸ニフェカラントの有効 性と陽性 T 波の形態に関する検討。心電図，2005； $25: 218 \sim 226$ 